\title{
HOUSEHOLD ENERGY DEMAND IN TYPICAL NIGERIAN RURAL COMMUNITIES
}

Olorunjuwon David Adetayo ${ }^{1}$, Gbenga John Oladehinde ${ }^{1}$,

Samson A. Adeyinka ${ }^{1}$, Adejompo Fagbohunka ${ }^{2}$

${ }^{1}$ Obafemi Awolowo University, Ile-Ife, Nigeria

${ }^{2}$ Adekunle Ajasin University, Akungba-Akoko, Nigeria

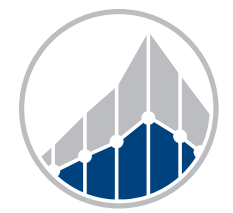

EUROPEAN JOURNAL OF BUSINESS SCIENCE AND TECHNOLOGY

Volume 7 Issue 2 ISSN 2694-7161

www.ejobsat.com

\begin{abstract}
This research investigates factors influencing domestic energy demand among rural households. Data were collected from 260 randomly sampled household heads in the study area. Descriptive statistics, ANOVA, and Tobit regression were used for the analysis. Tobit regression results revealed that gender, household size, income, occupation, farm size, and per capita expenditure were significant in influencing the use of fuelwood; age, gender, household size, occupation, education, and per capita expenditure for charcoal, while age, marital status, income, education and per capita expenditure were significant determinants in the use of kerosene. Also, income, occupation, and per capita expenditure were the factors influencing the use of electricity among rural households in the study area. The study concluded that apart from income, other household variables were significant in determining energy usage. The study, therefore, recommended that government and stakeholders should develop policies that will promote the use of safe, reliable, and clean energy sources in order to reduce the negative environmental consequences while also enhancing human life quality.
\end{abstract}

\section{KEY WORDS}

households' demand, domestic energy, fuel switching, fuel stacking, Nigeria

\section{JEL CODES}

I32, Q40, R20

\section{INTRODUCTION}

Energy is fundamental for social and economic growth as well as the development of any nation (Oyedepo, 2012; Chukwu et al., 2014). It is used as an essential input in most of the production processes. Provision, availability, and sustainable form of energy service are needed to increase human welfare and living standards. In the attainment of a certain level of comfort within the built environment, energy in different forms should be sufficient, economical, 
affordable, and reliable. People tend to live longer and healthier when there are sufficient and reliable energy services. Energy is required not only as a driving force for sustainable development but also in ensuring poverty reduction of any nation. According to Adetayo et al. (2020) power production and utilization are vital to development as most of the sectors of the economy rely on the availability of sufficient energy resources.

Household demand for energy is referred to as the utilization of energy, it involved energy that is used in the processing and production of food within a household (Adetunji et al., 2007). According to Emagbetere et al. (2016), household energy can be sub-divided into solid and non-solid fuel. While biomass (such as wood, animal dung, agricultural remains) and fossil fuel (such as coal) were examples of solid fuels, non-solid fuels include kerosene, gas, and electricity. The utilization of solid fuels such as biomass and fossil fuels through the provision of energy services has brought about different environmental-related issues. The occurrences of these environmental-related issues such as indoor and outdoor air pollution, urban air pollution, environmental degradation, deforestation, acid rain, and climate change among others have been on the increase in recent times.

Another alternative to biomass energy sources as identified by Modi et al. (2005) includes electricity, kerosene, liquefied petroleum gas (LPG), all of which were observed to be cleaner sources. However, scarcity of these alternative energy sources due to poor accessibility of rural community, as well as the unbearable prices which often exceeds their official pump prices has made most rural poor in the third world countries to depend on biomass such as wood, animal dung, and agricultural residue (Nnaji et al., 2012; Bisu et al., 2016). Kowsari and Zerriffi (2011) inserted that more than two and a half billion people in the world over depend on the traditional biomass fuel as their source of energy for cooking, lighting, and heating. Yamamoto et al. (2009) further added that biofuels are largely used particularly in developing countries. For example, Onoja and
Idoko (2012) reported with evidence from China that considerable numbers of households are used to the utilization of traditional biofuel in spite of their access to electricity. In Africa, International Energy Agency (2014) stated that biofuels account for about $50 \%$ of Africa's energy needs. In Nigeria, it was estimated that $70 \%$ comprising $42 \%$ of urban households and $86 \%$ of rural households consumed biofuel for their domestic needs (Gwatkin et al., 2000). Oyedepo (2012) argued that $86 \%$ of households still depend on fuelwood as their source of energy. This shows that a huge number of people in Nigeria and other developing countries still rely on biofuels for their domestic requirements.

Over-dependent on biofuel energy source for indoor cooking especially in the rural community has been considered a dangerous activity that is responsible for the death of more than 4.3 million people every year (WHO, 2010). According to Bisu et al. (2016), it is accounted for the death of about 396,000 people in subSaharan Africa in 2002. Indoor cooking using solid fuels has negative effects on human health (WHO, 2006). Some of the health effects include asthma, and cataracts, chronic obstructive lung disease in adults among others (Edwards and Langpap, 2008). World health organization (2006) reported that $2.7 \%$ of the global deaths in 2002 were associated with air pollution and disease.

In order to respond to health and environmental related issues that are attributed to the energy consumption behaviour of households, international organizations such as World Health Organization (WHO), United Nations (UN), and World Bank among others have made concerted efforts to address these issues. For instance, the United Nations launched sustainable energy for all (SE4ALL) with three major targets. The first target was to ensure universal access to affordable, reliable, sustainable, clean, safe, and modern energy services, the second target was to double the global rate of improvement in energy efficiency while the third target was to double the share of renewable energy in the global energy mix for all by 2030 (United Nations, 2013; Wilson, 2012). World Bank also launched Africa Clean 
cooking energy solutions to promote dissemination and adoption of clean cooking solutions for rural poor households in developing countries. Despite these efforts, however, the desired result has not been recorded as most rural households in sub-Saharan Africa still depend on unclean energy sources (Kichonge et al., 2014; Malla and Timilsina, 2014). Before these efforts can yield positive results, there is a need for empirical research that examines factors influencing energy demand among commonly used energy types (such as kerosene, fuelwood, charcoal, and electricity), especially due to the fact that household usage of any type of fuel for preparing and processing food varies across the globe.

Several studies have investigated factors influencing domestic energy choice and demand in a single study without considering the factors that are associated with each energy type (Ogwumike et al., 2014; Jan et al., 2012; Mekonnen and Köhlin, 2008). Apart from this, collapsing different energy types as a unit of analysis may be too broad and clumsy. It has been argued that different domestic energy sources have their peculiarity with regard to the associated determinants (Adepoju et al., 2012; Bisu et al., 2016). This study, therefore, investigates the factors that are influencing household demand of domestic energy types as well as the relationship between consumption behavior and fuel price. The domestic energy types such as firewood, charcoal, kerosene, and electricity were considered based on their availability and accessibility in the study area at the time of the survey. The goal of this study is to provide information on energy policy that could be adopted to ensure sustainable energy behaviour among rural households in Ese-Odo Local Government Area (LGA), Ondo State, Nigeria. The results of this study will contribute to the understanding of the consumption behavioural pattern of domestic energy with helpful recommendations that could ensure sustainable energy behaviour. This study will also be helpful in contributing to the literature on energy consumption of less considered areas in sub-Saharan Africa. The objective of this research is to examine the factors influencing domestic energy demand among rural households. In order to achieve the identified objective, this research provides answers to the following questions:

1. What is the socio-economic characteristics of the respondents?

2. What are the types of domestic energy and pattern of usage among rural households?

3. What are the factors affecting household choices of domestic energy usage?

4. Is there any significant relationship between fuel price and rate of consumption?

\section{LITERATURE REVIEW}

Energy is fundamental to sustainable development (Adamu et al., 2020; Güney and Kantar, 2020). It does not only accelerate social and economic progress but also enhances productivity. No society can develop without access to reliable and affordable energy. Other development goals may not be achieved without easy access to sustainable energy services. Energy has a direct impact on people, communities, and countries particularly in terms of economic growth, education, employment, and security (Rahmani et al., 2020; de Abreu et al., 2021). It also affects ecosystems which could be linked to climate change. According to United Nations (2013), the world faces complex challenges that are related to access, sustainability, and efficiency of modern energy services. In an attempted to address this, the UN SG's Sustainable energy for all (SE4ALL) initiative was launched with the aim of achieving three major objectives by 2030. These objectives include ensuring universal access to modern energy services, doubling the share of renewable energy in the global energy mix, and doubling the global rate of improvement in energy efficiency. This initiative is directly linked to the 7th Sustainable Development Goal (SDG) which is to ensure affordable, reliable, sustainable, and modern energy for all 
by 2030. This goal was promoted by the United Nations in an attempt to support the increase of sustainable energy consumption (SDG 2018). Despite this initiative, it has been observed that there is still a wide gap between the level of achievement of the seventh Goal of the 2030 SDGs in developed and developing countries. While developed countries have achieved this goal in investing on the required infrastructure through subsidies and specific funding; developing countries particularly countries in subSaharan Africa and some parts of Asia, have not been able to achieve much. Most people especially in sub-Saharan Africa still lack access to reliable and clean energy supplies (Egaña del Sol and Flanders, 2020). World Energy Council (2016) estimated that three billion people around the world still rely on simple stoves or open fires that burn wood, animal dung, or coal to cook and heat their homes.

Evidence abounds in the literature that demands for household energy for cooking, heating, lighting, and transportation varies from country to country. For example, in China, Leiwen and O'Neill (2003) reported that electricity and biomass are common types of fuel among urban households. Firewood and Liquified Gas were mostly used in Urban areas of Guatemala (Energy Sector Management Assistance Program, 2000). In India, the use of biomass fuel stove was commonly practiced for making traditional bread among wealthy households (Saatkamp et al., 2000). In certain regions of Mexico, some households prefer to cook certain food (tortillas) with firewood rather than using Liquified Gas irrespective of their level of income due to the taste and texture provided by fuelwood (Masera et al., 2000). According to Bhattacharyya (2011), the reason for this variation is due to differences in the level of economic development, climatic condition, technological advancement, policies, and other factors. Apart from the variation in the demand for household energy, it has been observed that most households in developing countries depend majorly on biomass fuel as their source of energy for different purposes especially cooking, heating, and lighting (Adamu et al., 2020). De Abreu et al. (2021) and Bonjour et al.
(2013) argued that demand for cooking fuels is estimated to fall because of fuel switching towards modern fuels. It was reported that the percentage of households that solely use solid fuels has reduced globally, particularly from $62 \%$ in 1980 to $41 \%$ in 2010. Nevertheless, the number of persons using solid fuels among low-income households in developing countries is still increasing. In rural communities of developing countries, IEA (2013) reported that more than one billion people do not have access to electricity and over two billion people still rely on traditional biomass (fuelwood, charcoal, agricultural residues, and dung). In recent times, such traditional biomass is largely used among rural households in sub-Saharan Africa especially Nigeria. Several studies have identified income as one of the major drivers of energy choice made by households (Barnes and Floor, 1996; ESMAP, 2000; ESMAP, 2003; Elias and Victor, 2005; Onyekuru and Eboh, 2011; Wuyuan et al., 2008; Pachauri, 2004). For example, while Wuyuan et al. (2008) suggested that there is a strong correlation between an increase in household income and usage of modern fuels, Onyekuru and Eboh (2011) observed a positive correlation between household income and domestic energy demand. Babanyara and Saleh (2010) discovered that situational factors influencing the choice of fuelwood at the expense of kerosene were poverty and hikes in the price of kerosene. Song et al. (2012) reported that family size and household income were the critical factors influencing the demands of fuelwood in the USA. However, in the study of Jan et al. (2012), it was submitted that there are still other factors that determine the demand for household energy apart from income. These include household characteristics (such as age, gender, level of education, and type of employment), energy price, location, access to alternative energy sources, consumer preferences (such as food tastes and cooking practices), ownership status, per capita expenditure, sociocultural and environmental factors (Jan et al., 2012; Lee, 2013; Svoboda and Brčák, 2013; Nlom and Karimov, 2015; Eakins, 2013; Mensah and Adu, 2013; Heltberg, 2005; Leth-Petersen, 2002; Warsco, 1994; Naibbi and Healey, 2013; 
Emagbetere et al., 2016; Yu et al., 2012; Kuhe and Bisu, 2019). Despite the availability of studies on factors affecting the choice of household energy, it has been observed that most of these studies were focused on urban centers while rural areas were not considered. Motivating factors that influence demand for household energy in rural areas may be different from urban centres due to the difference in socio-economic status, culture, and geographical location.

A good number of theories have been reported on household energy choice and basic factors influencing their preference. One of the theories that have been adopted in investigating household energy choice is the 'Energy Ladder Model'. Energy Ladder Model according to Heltberg (2004) is classified into three, namely; traditional fuel (such as wood, dung, agricultural residue); transitional fuel (such as kerosene and coal), and modern fuel (such as natural gas and electricity). This model emphasized more on income in explaining fuel choice across three stages linear switching process, by switching completely to a higher level of fuel as income increases (Farsi et al., 2007; Osiolo, 2009). The model assumes that low-income households tend to use traditional fuels that are cheap and available locally, but switch towards transitional fuel as their income improves. The household would further switch from transition to modern fuel as household income increases. Although energy ladder model assumed income as the only factor that makes household to switch fuel from one ladder to another, the model has neglected the interaction of other factors that characterize energy transition such as household preference, cultural factor among other. In developing countries, it has been observed that households do not switch to modern fuel but rather consume different fuels which may include a combination of solid fuels with non-solid fuels (Buba et al., 2017). Hence, rather than moving up the ladder as the income improves, households choose different fuels based on their needs, preferences, and budgets (World Bank, 2003). This leads to the model of fuel stacking (multiple fuel use), an alternative to the energy ladder model. Fuel stacking assumes multiple fuel usage instead of switching fuel as indicated by the energy ladder model (van der Kroon et al., 2013; Herington and Malakar, 2016). The fuel stacking model has been preferred by many researchers such as Ogwumike et al. (2014), Malla and Timilsina (2014), and Yonemitsu et al. (2015) who observed that household energy use pattern is not only dependent on income but is a function of several factors such as cultural, economic, social or even personal preferences (Pachauri and Spreng, 2004).

\section{METHODS AND MATERIALS}

\subsection{Study Area}

Ese-Odo local government is located in the riverine area of the southern Ondo State. It shares boundaries in the south to the large Local Government, lrele Local Government Areas in the North East, Okitipupa Local Government Area to the North West. The local government also shares boundaries with Delta and Edo State of the South East. The Local Government is within the equatorial evergreen swampy forest which is drained by important rivers: Oluwa, Urogbo, Out, Oputoru, and Opuakpatakubu, among others. which of transportation between the people and other areas.
Ese-Odo Local Government was created out of the defunct Ilaje-Ese-Odo Local Government Area on $2^{\text {nd }}$ January 1997, with headquarters at lgbekebo, Ondo State by General Sani Abacha's administration. The bitumen and oil-rich Local Government is made up of two major ethnic groups: the ljaw Apoi and Arogboljaw, who have similar historical antecedents. The local government has a population of 154,978 with a large landmass and water. It consists of more than one hundred and twenty towns and villages covering an area of over $1,600 \mathrm{~km}^{2}$. Primary data were used for the study. They were collected from a cross-sectional survey of 260 households using structured questionnaires. 


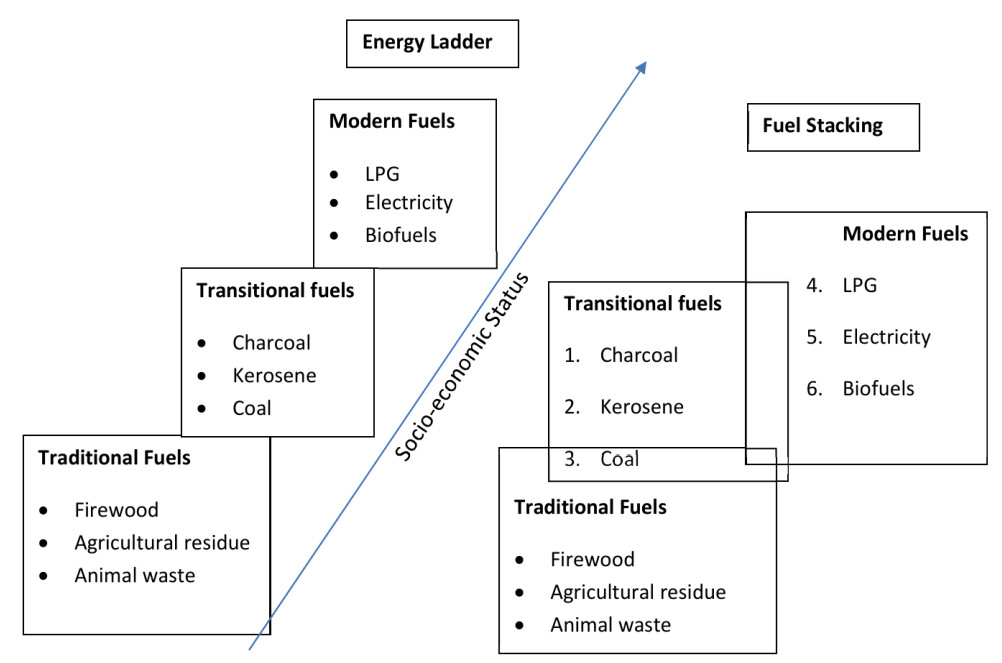

Fig. 1: Energy Transition Process (adopted from Schlag and Zuzarte, 2008)

A multi-stage sampling procedure was employed in selecting representative households. The first stage involved the division of the local government area into the ten (10) existing political wards as delineated by Independent National Electoral Commission. All the wards such as Arogbo 1, Arogbo 2, Arogbo 3, Ukparamo 1, Ukparamo 2, Apoi 1, Apoi 2, Apoi 3, Apoi 4, and Apoi 5 were selected for the study. The second stage involved the random selection of thirteen (13) households from each of these wards. This makes a total of 260 respondents that were selected for the survey.

\subsection{The Econometric Model}

Descriptive statistics: Descriptive analysis such as tables (frequency and percentage) and bar graph to analyse the socio-economic characteristics of the respondents in the study area. It was also used for other variables (such as land ownership, farm size, land tenure system, and types of domestic energy) of the study.

Inferential statistics: Inferential statistics such as Tobit regression and ANOVA. While Tobit regression analysis was used to estimate the factors influencing household choices for different domestic energy types, ANOVA analysis was used to explore the causal relationship between fuel price and consumption rate.
Tobit Regression Model: Tobit regression model is a statistical model which was proposed by Tobin in 1958. It is used to explain the causal relationship between a non-negative dependent variable and an independent one assuming that there is a latent variable which linearly depends on the independent variable through a parameter (beta) that determines the relationship between the independent and latent variable. Tobit model is the most common censored regression model appropriate for analysing dependent variables with upper or lower limits (Mazibuko and Antwi, 2019). Verbeek (2004) observed that Tobit regression is usually the best model when the dependent variable is continuous and has a constrained rage, represents a positive variable. This statistical model has previously been used in studies such as Olagunju and Ajiboye (2010); Hussainey and Al-Najjar (2011); Odah et al. (2017); Amore and Murtinu (2019). Tobit model answers both the question on factors influencing a decision and the factors that determine such a decision. Generally, the Tobit model uses Maximum Likelihood Estimation (MLE) method to estimate the parameters assuming normality and homoscedasticity conditions.

The model is specified as:

$$
\begin{aligned}
& y_{i}^{*}=\beta^{t} x_{i}+e_{i}, \quad i=1,2, \ldots, n, \\
& y_{i}=y_{i}^{*} \text { if } y_{i}^{*}>0, \text { and } y_{i}=0 \text { otherwise, }
\end{aligned}
$$


where $n$ is the number of the observations, $y_{i}$ is the observed contingent valuation by individual $i$, which is also known as dependent variable (usage of different energy types such as fuelwood, charcoal, kerosene, and electricity), $x_{i}$ is a vector of the independent variable. These are explanatory variables such as socioeconomic characteristics, demographic characteristics, per capita expenditure, and farm size (acre), $\beta$ denotes the vector of estimated parameters or coefficients, $\beta^{t} x_{i}$ is the scalar product of two vectors, and $e_{i}$ is a normally and independently distributed error term with zero mean and constant variance $\left(\sigma^{2}\right)$. It is assumed to be an implicit, stochastic index (latent variable) equal to $y_{i}^{*}$ which is observed only when positive. According to the equation $\left(I_{i}=\beta^{t} x_{i}\right), y_{i}^{*}$ is produced by a conventional linear regression model based on the estimates that was put forward by Odah et al. (2017).

Then, $y_{i}, x_{i}$ is generally referred to as the independent variable and the dependent variables known for each is $i=1,2, \ldots, n$. In overall, it is specifically defined in this way:

$$
y_{i}=\beta^{t} x_{i}+e_{i} \text { if RHS }>0
$$

According to Odah et al. (2017) and Amore and Murtinu (2019) were is familiar with Tobit Regression Model, proposed the dependent variable observer $y_{i}$ for observers $i=1,2, \ldots, n$ and this could be arrived at based on the following:

$$
y_{i}=\max \left(y_{i}^{*}, 0\right)
$$

If $y_{i}$ and $x_{i}$ are not noted when $y_{i}^{*} \leq 0$ then perhaps the model is recognized as truncated regression model, in other phrase, the data $y_{i}^{*}$ and $x_{i}$ are noted only when $y_{i}^{*} \leq \gamma$. The coefficients was arrived at through Tobit model using STATA computer software (STATA 15) (Mazibuko and Antwi, 2019; Odah et al., 2017).

The study uses a Tobit regression analysis to estimate the factors influencing household choices for different domestic energy types. The selection of Tobit regression analysis was determined due to zero expenditure recorded by some households on the domestic energy types. Using Tobit regression analysis in this study was also supported by Adepoju et al.
(2012) who inserted that Tobit regression is used when there is a record of zero expenditure by some households on their energy types. It was further established by Adepoju et al. (2012) that zero expenditure makes parameter computation from conventional Ordinary Least Square (OLS) regression to be inefficient. The Tobit model was implemented with Maximum Likelihood Estimation (MLE) and censoring at the lowest (zero) expenditure level. Tobit regression analyses were carried out for the four types of domestic energy identified in the study area, namely firewood, charcoal, kerosene, and electricity. For this study, the Tobit regression model is expressed as follows in functional forms:

$$
Y_{i}=f\left(X_{1}, X_{2}, X_{3}, X_{4}, X_{5}, X_{6}, X_{7}\right)
$$

The variables in the model were presented below:

- $Y_{i}=$ Usage of different energy types (such as fuelwood, charcoal, kerosene, and electricity)

- $X_{1}=$ Age of the respondents

- $X_{2}=$ Level of education

- $X_{3}=$ Monthly income

- $X_{4}=$ Gender

- $X_{5}=$ Marital Status

- $X_{6}=$ Per capita expenditure

- $X_{7}=$ Household size

- $X_{8}=$ Farm size

- $X_{9}=$ Occupation of the household heads

Choice of ANOVA (analysis of variance). In the process of exploring the causal relationship between variables, ANOVA can use be used to compare the means of two or more groups on the dependent variable (Green and Salkind, 2010). It is used to determine whether there are any statistically significant differences between the means of two or more independent (unrelated) groups. ANOVA is used for understanding whether different levels of factors have an impact on the responses, in a factor-response model. The assumption for ANOVA is that (i) independent random sample. The sample must contain observations independently chosen from each other. In order words, sampling one observation must not influence the sampling of another observation. (ii) The numerical variable 
must be normally distributed in each group. (iii) The residuals must be normally distributed. (iv) All groups must not suffer from heterogeneity. The variance must be equal in all groups included in the large samples (Hair et al., 2006).
ANOVA analysis was used to explore the causal relationship between fuel price and consumption rate (Bisu et al., 2016). It was used to show the level of significance between the rate of consumption and the price of each fuel type.

\section{RESULTS AND DISCUSSION}

\subsection{Socio-economic Characteristics of the Respondents}

Tab. 1 shows the socio-economic attributes of the respondents in the study area. The result reveals that $66.5 \%$ of the household heads were males while $33.3 \%$ were female. It could be inferred that there were more men than women household heads. This is probably due to their role and responsibility in the family especially in the provision of domestic energy for indoor cooking, heating, and lighting. It was also observed that the majority of the respondents $(71.5 \%)$ were between 31 and 60 years of age, $3.5 \%$ were above 60 years old, while $25.0 \%$ were below 30 years. This shows that there was more active population compared to other age groups in the study area. The proportional representation of more active population is an indication that demand for domestic energy might high in rural communities. Moreover, $29.2 \%$ of the households had between 1 to 5 members, $68.5 \%$ had between 6 and 10 members, while $2.3 \%$ of the respondents' household size had more than 10 members. This means that more than half of the household heads had 6 to 10 members that depend on them. This could probably increase the demand for domestic energy. The result of this study corroborates the findings of Adepoju et al. (2012) who observed that most of the household heads in traditional society have more than 6 family members. Findings in Tab. 1 show that most of the respondents $(52.3 \%)$ had no formal education, $33.1 \%$ had primary education, $12.7 \%$ had secondary education while only $1.9 \%$ had tertiary education. It could be deduced that more than half of the respondents were not formally educated and their level of education can influence the type of domestic energy that is used for cooking, heating, and lighting.
Tab. 1: Distribution of socio-economic characteristics of the respondents

\begin{tabular}{|c|c|c|}
\hline Socio-economic characteristics & Frequency & Percentage \\
\hline \multicolumn{3}{|l|}{ Gender } \\
\hline Male & 173 & 66.5 \\
\hline Female & 87 & 33.5 \\
\hline \multicolumn{3}{|l|}{ Age } \\
\hline Below 30 & 65 & 25.0 \\
\hline $31-60$ & 186 & 71.5 \\
\hline Above 60 & 9 & 3.5 \\
\hline \multicolumn{3}{|l|}{ Household Size } \\
\hline $1-5$ & 76 & 29.2 \\
\hline $6-10$ & 178 & 68.5 \\
\hline Above 10 & 6 & 2.3 \\
\hline \multicolumn{3}{|l|}{ Education } \\
\hline No formal education & 136 & 52.3 \\
\hline Primary education & 86 & 33.1 \\
\hline Secondary education & 33 & 12.7 \\
\hline Tertiary education & 5 & 1.9 \\
\hline \multicolumn{3}{|l|}{ Marital Status } \\
\hline Married & 184 & 70.8 \\
\hline Divorced & 27 & 10.4 \\
\hline Widowed & 17 & 6.5 \\
\hline Separated & 32 & 12.3 \\
\hline \multicolumn{3}{|l|}{ Occupation } \\
\hline Farming & 195 & 75.0 \\
\hline Artisan & 18 & 6.9 \\
\hline Trading & 39 & 15.0 \\
\hline Salary earners & 8 & 3.1 \\
\hline \multicolumn{3}{|l|}{ Monthly Income (A) } \\
\hline Below $¥ 18,000(\$ 47.1)$ & 78 & 30.0 \\
\hline ミ18,001-55,000 (\$47.1-143.9) & 174 & 67.0 \\
\hline §55,001-74,000 (\$143.9-193.7) & 4 & 1.5 \\
\hline$\$ 74,001(\$ 193.7)$ above & 4 & 1.5 \\
\hline
\end{tabular}


Further analysis in Tab. 1 also shows that $70.8 \%$ of the respondents were married, $10.1 \%$ were divorced, $6.5 \%$ were widowed, while $12.3 \%$ were separated. This is an indication that the majority of the respondents were married as more importance was attached to marriage and singleness. The proportional representation of those that are married may influence the level of usage of domestic energy compared to those that are single, divorced, or widowed. Moreover, $75.0 \%$ of the respondents were farmers, $6.9 \%$ were artisan, $15.0 \%$ were into trading, while $3.1 \%$ were salary earners. It could be inferred that the majority of the household heads had farming as their primary occupation. This finding truly reflects the common occupation of the study area. The table also shows that $97.0 \%$ of the respondents earned below $\$ 55,000$ $(\$ 143.9)$ while only about $3.0 \%$ earned above $\$ 55,001$ (\$143.9) per month with an average income of $\$ 26,896.15$ (\$70.4). (1 USD $=\$ 382$ as at when data was collected). It suggests that the majority of the respondents earned below the Nigerian minimum wage despite the fact that they are in the rural area. The monthly income of the household heads might influence the type of energy usage as households with higher income tend to use clean and safe energy while low-income households tend to use energy that might have a negative effect on human health and the environment.

\subsection{Land Ownership, Farm Size, and Land Tenure System}

Analysis of land ownership, farm size, and land tenure system is presented in Tab. 2. The findings confirmed that $74.6 \%$ of the respondents owned a farm, while $25.4 \%$ did not. This result corroborates earlier findings that most of the household heads were engaged in farming activities as either primary occupation. The table also reveals that $25.4 \%$ of the respondents had no farmland, $68.8 \%$ had less than 2 acres, while $5.8 \%$ had more than 2 acres. It can be observed that most of the respondents had less than 2 acres of land, an indication that they are small landholders. Analysis in Tab. 2 shows that the predominant land tenure system was through freehold system $(50.8 \%)$, followed by leasehold system $(23.8 \%)$ and communal system $(2.3 \%)$ while others that were unidentified were accounted for $3.1 \%$. This implied that the freehold system especially through inheritance was generally practiced in the study area.

Tab. 2: Land ownership, farm size, and land tenure system

\begin{tabular}{lcc}
\hline Description & Frequency & Percentage \\
\hline Own Land & 194 & 74.6 \\
Yes & 66 & 25.4 \\
No & & \\
\hline Farm Size & 66 & 25.4 \\
None & 95 & 36.5 \\
$<1$ acre & 84 & 32.3 \\
$1-2$ acres & 15 & 5.8 \\
$>2$ acres & & \\
\hline Land Tenure System & 58 & 22.3 \\
Communal & 132 & 50.8 \\
Freehold & 62 & 23.8 \\
Leasehold/tenants & 8 & 3.1 \\
Others & & \\
\hline
\end{tabular}

\subsection{Types of Domestic Energy and Pattern of Usage among Rural Households}

In order to examine the types of energy sources in the study area, four predominant types of domestic energy can be identified. These include firewood, charcoal, kerosene, and electricity. These types of domestic energy were adopted in this study. Three major uses were also observed in the study area, namely cooking, heating, and lighting. Respondents were asked to choose their common sources of energy with reference to what the energy is been used for. Findings on the types of energy and pattern of usage were presented in Tab. 3. The table revealed that $48.1 \%$ of the respondents used kerosene for cooking, $40.3 \%$ used it for heating while $37.7 \%$ used it for lighting. It can be inferred that the majority of the respondents used kerosene for cooking. Also, $38.5 \%$ of the respondents used fuelwood for cooking, $33.3 \%$ used it for heating and $5.7 \%$ used it for lighting. Fuelwood was commonly used for heating especially at night. 
Tab. 3: Sources of energy and modes of usage

\begin{tabular}{lccccccrrr}
\hline & \multicolumn{2}{c}{ Cooking } & \multicolumn{2}{c}{ Heating } & \multicolumn{2}{c}{ Lighting } & \multicolumn{2}{c}{ Total } \\
Fuel types & Frequency & $\mathbf{\%}$ & Frequency & $\mathbf{\%}$ & Frequency & \% & Frequency & \% \\
\hline Fuel wood & 52 & 38.5 & 24 & 33.3 & 3 & 5.7 & 84 & 32.2 \\
Charcoal & 12 & 8.9 & 10 & 13.9 & 1 & 1.9 & 23 & 8.8 \\
Kerosene & 65 & 48.1 & 29 & 40.3 & 20 & 37.7 & 109 & 41.9 \\
Electricity & 6 & 4.4 & 9 & 12.5 & 29 & 54.7 & 44 & 16.9 \\
\hline
\end{tabular}

About $8.9 \%$ of the respondents used charcoal for cooking, $13.9 \%$ used it for heating while $1.9 \%$ used it for lighting. Electricity was commonly used for lighting $(54.7 \%)$, other ways of usage were for cooking $(4.4 \%)$ and lighting $(12.5 \%)$. The study also reveals that households spent an average of $\$ 176.07$ and $\$ 138.61$ respectively on fuelwood and charcoal while \$843.30 and \#1,209.48 were the average amounts spent on kerosene and electricity respectively per month. A general summary of this finding was that charcoal was the least used especially for lighting while electricity was the least used for cooking. This could probably be as a result of the high cost of electricity bill which may quite be expensive on the part of the respondents and also due to its erratic supply. This finding agrees with Bisu et al. (2016), Mekonnen and Köhlin (2008).

\subsection{Household Per Capita Expenditure and Energy Ladder Model}

As earlier explained 'energy ladder model' assumes that households tend to switch their fuel usage from biofuel to advance energy sources as income improves or increases. Nevertheless, this study used per capita expenditure instead of household income (Ogwumike et al., 2014). Based on the energy ladder model, it is expected that households with a higher per capita expenditure category would use electricity as their main fuel while middle-income earners would consider the use of kerosene. The low-income households would use charcoal and firewood as their main fuel.
Fig. 2 reveals the pattern of energy usage among the households in different per capita expenditure groups. While the horizontal axis shows the per capita expenditure categories in Naira, the vertical axis shows the percentage of energy usage across the types. The analysis in Fig. 2 shows that usage of fuelwood and charcoal as the main fuel decreases as per capita expenditure increases among the households. While the proportion of households that were using kerosene as their main fuel increase as per capita expenditure improves, the proportion of those that were using electricity also rose as per capita expenditure moves higher. This pattern of energy demand is in agreement with the transition stage of the energy ladder model, whereby low-income households used traditional biomass, middle-income households used transition fuel while high-income households used advanced or modern fuel. It was further observed that some fuels were not abandoned totally. While some households switched from one type of fuel to another, others adopted energy sacking (multiple use of fuel). Instead of switching lower energy types as expenditure increases, households prefer to stack different forms of energy. This is in agreement with household preferences. Depending on different reasons, some households at higher per capita expenditure group were still able to consider fuelwood energy source. This is an indication of multiple fuel usage (fuel stacking). Multiple usages of different types of fuel among high per capita expenditure group could be explained by different factors other than income as established by Jan et al. (2012), Pachauri and Spreng (2004), and Démurger and Fournier (2011). 


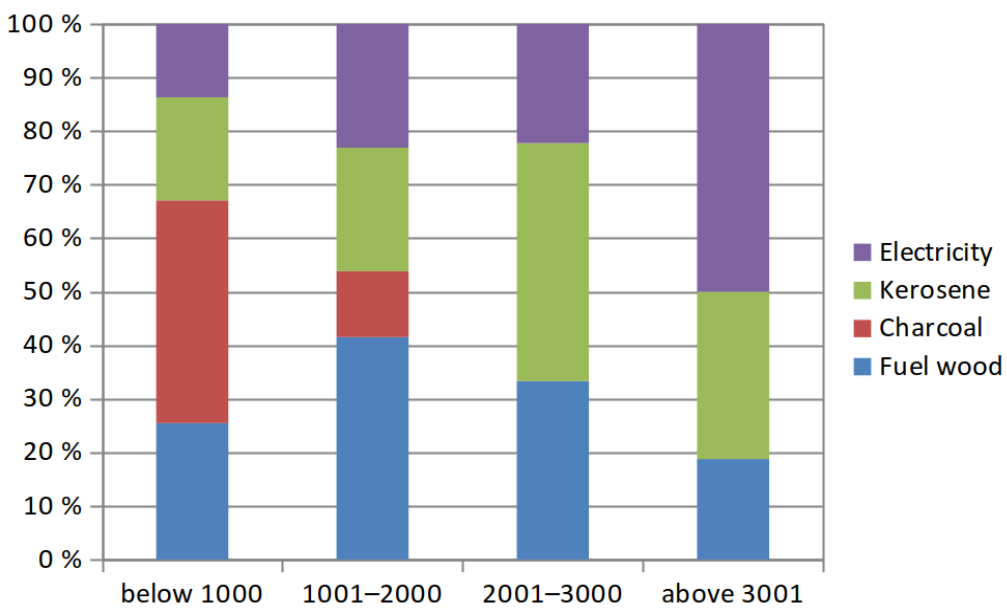

Fig. 2: Energy usage and per capita expenditure categories

\subsection{Factors Affecting Household Choices of Domestic Energy Usage}

Tobit regression analysis in Tab. $4-7$ was carried out to determine the factors that influence household choices of domestic energy in the study area. Four regression models were estimated separately for the types of domestic energy, namely; fuelwood, charcoal, kerosene, and electricity. Explanatory variables that were considered in each of the models included age, level of education, monthly income, gender, marital status, farm size, per capita expenditure, household size, and occupation of the household heads.

\subsubsection{Determinants of Fuel Wood}

The result of Tobit regression model as shown in Tab. 4 was used to test the determinants of fuelwood. The variance inflation factor (VIF) was used to determine the multicollinearity between the explanatory variables. As a rule of thumb, multicollinearity is a potential problem when VIF is greater than 4; and, a serious problem when it is greater than 10 (Oke et al., 2019). The output in Tab. 4 below shows that VIF values were less than 4 . This indicates that the model was free from collinearity. The diagnostic statistics in Tobit regression analysis in Tab. 4 reveals that the chi-square value (LR-statistics) for the model is significant at $1 \%$ and $5 \%$ level which means that the independent variables jointly influence respondents' likelihood of using fuelwood. The Pseudo $R$-squared indicates that $57.3 \%$ of the variance was explained by the independent variables. The result from the study showed that the coefficients of most of the variables hypothesized to influence the household choices of domestic energy have the expected signs. The signs show the direction of change in the likelihood of using fuelwood over other sources of domestic energy. While a positive sign shows an increase in the probability of usage, a negative sign explains the converse. The results showed that out of the 9 variables that were included in the model, the coefficients of six variables were statistically significant at $1 \%$ and $5 \%$ in influencing household choices of domestic energy.

The results of Tobit regression model shows that gender $(t=1.99 ; p<0.05)$, household size $(t=0.82 ; p<0.05)$, monthly income $(t=-0.26 ; p<0.05)$ and farm size $(t=$ $1.44 ; p<0.05)$ were significant at $5 \%$ level while occupation $(t=4.50 ; p<0.01)$ and per capita expenditure $(t=-4.64 ; p<0.01)$ were significant at $1 \%$ level. The result means that probability of using fuel wood varied between male and female household head, as female household head tend to use fuel wood than male household head. Household size is positively signed which means that large household has higher probability of using fuel wood than small household size. 
Tab. 4: Tobit regression results of factors influencing demand for fuelwood

\begin{tabular}{|c|c|c|c|c|c|c|c|}
\hline \multirow{3}{*}{$\begin{array}{l}\text { Fuelwood } \\
\text { Age }\end{array}$} & \multirow{3}{*}{$\begin{array}{r}\text { Coefficient } \\
-0.0040661\end{array}$} & \multirow{3}{*}{$\frac{\text { Standard error }}{0.0064517}$} & \multirow{3}{*}{$\begin{array}{c}t \text {-value } \\
-0.63\end{array}$} & \multirow{2}{*}{\multicolumn{2}{|c|}{$95 \%$ conf. interval }} & \multicolumn{2}{|c|}{ Collinearity Statistics } \\
\hline & & & & & & Tolerance & VIF \\
\hline & & & & -0.0167725 & 0.0086403 & 0.648 & 1.542 \\
\hline Gender & -0.2147976 & 0.1080795 & $1.99 * *$ & -0.4276559 & -0.0019393 & 0.885 & 1.130 \\
\hline Marital status & -0.0115306 & 0.0616727 & -0.19 & -0.1329925 & 0.1099313 & 0.558 & 1.793 \\
\hline Household size & 0.0181806 & 0.0221323 & $0.82^{* *}$ & -0.0254081 & 0.0617692 & 0.826 & 1.211 \\
\hline Income & $1.01 \mathrm{e}-06$ & $3.90 \mathrm{e}-06$ & $-0.26^{* *}$ & $-6.67 e-06$ & $8.68 \mathrm{e}-06$ & 0.756 & 1.323 \\
\hline Occupation & 0.0134072 & 0.0484389 & $4.50^{* * *}$ & -0.0819913 & 0.1088056 & 0.702 & 1.424 \\
\hline Education & 0.1049038 & 0.0662785 & 1.58 & -0.0256291 & 0.2354367 & 0.815 & 1.227 \\
\hline Farm size & -0.1326777 & 0.0920570 & $-1.44^{* *}$ & -0.3139803 & 0.0486248 & 0.812 & 1.232 \\
\hline $\begin{array}{l}\text { Per capita } \\
\text { expenditure }\end{array}$ & -0.0003057 & 0.0000659 & $-4.64^{* * *}$ & -0.0004356 & -0.0001759 & 0.980 & 1.021 \\
\hline Constant & 1.2099410 & 0.3182054 & 3.80 & 0.5832485 & 1.8366340 & & \\
\hline
\end{tabular}

Notes: *** Significant at $1 \%$; ** Significant at 5\%; Number of observations $=260$; LR chi-square $(9)=113.45$; Prob $>\chi^{2}=0.0002 ;$ Pseudo $R^{2}=0.5730 ;$ Log likehood $=-258.57471$.

Household income is negatively signed which implies that as household income decreases, the demand for fuelwood increases. This means that an increase in respondents' income will decrease the likelihood of using fuelwood. This is probably because higher-income earners tend to go for safe and clean energy either for cooking or lighting.

Farm size and occupation are expected to influence the probability of using fuelwood. This is because the majority of the respondents were farmers and fuelwood used in cooking was gotten from their farm in the study area. The negative sign of per capita expenditure implies that lesser expenses incurred on fuelwood per month increase demand for fuelwood. This suggests that fuelwood is an 'inferior' energy source among households. This result is expected as fuelwood is predominantly used for cooking among rural dwellers. This study corroborates the findings of Babanyara and Saleh (2010). Other variables such as age, marital status, and education were not statistically significant in determining the demand for fuelwood. This implied that the age of the respondents, marital status, and level of educational attainment does not determine the household choice for fuelwood.

\subsubsection{Determinants of Charcoal}

The result of Tobit regression model as shown in Tab. 5 was used to test the determinants of charcoal. The variance inflation factor (VIF) was used to determine the multicollinearity between the explanatory variables. The VIF values were less than 4 , which indicates that the model was free from collinearity. The diagnostic statistics of Tobit regression analysis in Tab. 5 reveals that the chi-square value (LR-statistics) for the model is significant at $1 \%$ and $5 \%$ level which means that the independent variables jointly influence respondents' probability of using charcoal. The Pseudo $R$-squared indicates that $72.2 \%$ of the variance was explained by the explanatory variables. The result showed that the coefficients of most of the variables hypothesized to influence the household choices of domestic energy have the expected signs. The results showed that out of the 9 variables that were included in the model, the coefficients of six variables were statistically significant at $1 \%$ and $5 \%$ in influencing household choices of domestic energy.

The result shows that gender $(t=2.99$; $p<0.01)$, occupation $(t=2.61 ; p<0.01)$, and per capita expenditure $(t=-4.78 ; p<0.01)$ were significant at $1 \%$ level while household size $(t=2.55 ; p<0.05)$, level of education $(t=-0.55 ; p<0.05)$ and age $(t=-0.48$; $p<0.05)$ were significant at $5 \%$ level.

The positive sign of gender shows that tendency to use charcoal varied between male and female household heads. The choice of charcoal as the source of energy is determined 
Tab. 5: Tobit regression results of factors influencing demand for charcoal

\begin{tabular}{lccccccc}
\hline Charcoal & Coefficient & Standard error & $t$-value & 95\% conf. interval & \multicolumn{2}{c}{$\begin{array}{c}\text { Tollinearity Statistics } \\
\text { Tolerance }\end{array}$} & VIF \\
\hline Age & 0.0027059 & 0.0055792 & $-0.48^{* *}$ & -0.0082821 & 0.0136939 & 0.648 & 1.542 \\
Gender & 0.2819582 & 0.0944281 & $2.99^{* *}$ & 0.0959858 & 0.4679307 & 0.885 & 1.130 \\
Marital status & 0.0202660 & 0.0532926 & 0.38 & -0.0846917 & 0.1252237 & 0.554 & 1.805 \\
Household size & 0.0184805 & 0.0189642 & $2.55^{* *}$ & -0.0188689 & 0.0558298 & 0.825 & 1.212 \\
Income & $-3.16 \mathrm{e}-07$ & $3.41 \mathrm{e}-06$ & -0.09 & $-7.04 \mathrm{e}-06$ & $6.41 \mathrm{e}-06$ & 0.756 & 1.323 \\
Occupation & -0.1155311 & 0.0442686 & $2.61^{* * *}$ & -0.2027164 & -0.0283458 & 0.702 & 1.424 \\
Education & -0.0321171 & 0.0586623 & $-0.55^{* *}$ & -0.1476501 & 0.0834160 & 0.815 & 1.227 \\
Farm size & -0.1368407 & 0.0788789 & -1.73 & -0.2921897 & 0.0185082 & 0.812 & 1.232 \\
Per capita & 0.0002541 & 0.0000532 & $-4.78^{* * *}$ & 0.0001493 & 0.0003588 & 0.980 & 1.021 \\
expenditure & & & & & & & \\
Constant & 0.0979354 & 0.2819491 & 0.35 & -0.4573520 & 0.6532229 & \\
\hline
\end{tabular}

Notes: *** Significant at $1 \%$; ** Significant at $5 \%$; Number of observations $=260 ;$ LR chi-square $(9)=145.55$; Prob $>\chi^{2}=0.0000 ;$ Pseudo $R^{2}=0.7220 ;$ Log likehood $=-247.61674$.

by occupation. The reason for this is not farfetched from the fact that the majority of the respondents are farmers. The probability of using charcoal is therefore high among farmer households than other households that are not farmers. Average monthly expenditure on the usage of charcoal is negatively signed. This means that lesser expenses on the use of charcoal increase respondents' demand for charcoal and higher expenses on charcoal reduce the usage of charcoal. The negative sign of the level of education implies that lesser-educated households demand for more charcoal than households with more educated people. Moreover, the positive sign of household size reveals that larger household size tends to demand for more charcoal than smaller households.

Negative significance of respondents' age shows that demand for charcoal decreases as households head get older. Information from field observation in the study area reveals that charcoal is very scarce in the villages and the process involved in igniting charcoal fully is stressful. This may discourage the use of charcoal among older household heads.

Other variables such as marital status, income, and farm size were not statistically significant in determining the demand for charcoal. This implied that the marital status of the respondents, monthly income, and farm size does not influence the household choice for charcoal.

\subsubsection{Determinants of Kerosene}

The result of Tobit regression model as shown in Tab. 6 was used to test the determinants of Kerosene. The variance inflation factor (VIF) was used to determine the multicollinearity between the explanatory variables. The VIF values of the explanatory variables were less than 4. This indicates that the model was free from collinearity. The diagnostic statistics of Tobit regression analysis in Tab. 6 reveals that the chi-square value (LR-statistics) for the model is significant at $1 \%$ and $5 \%$ level which means that the independent variables jointly influence respondents' probability of using kerosene. The Pseudo $R$-squared indicates that $82.3 \%$ of the variance was explained by the explanatory variables. The results from the study showed that the coefficients of most of the variables hypothesized to influence household demand for kerosene have the expected signs. The results in Tab. 6 show that excluding the constant term, out of the 9 variables that were included in the model, the coefficients of five variables were statistically significant at $1 \%$ and $5 \%$ in influencing household demand for kerosene.

The result shows that income $(t=-0.38$; $p<0.01)$ was significant at $1 \%$ level while marital status $(t=2.26 ; p<0.05)$, level of education $(t=0.61 ; p<0.05)$ and age $(t=1.66 ; p<0.05)$, per capita expenditure $(t=2.77 ; p<0.05)$ were significant at $5 \%$ level. 
Tab. 6: Tobit regression results of factors influencing demand for kerosene

\begin{tabular}{|c|c|c|c|c|c|c|c|}
\hline \multirow{3}{*}{$\begin{array}{l}\text { Kerosene } \\
\text { Age }\end{array}$} & \multirow{3}{*}{$\begin{array}{r}\text { Coefficient } \\
0.0078956\end{array}$} & \multirow{3}{*}{$\frac{\text { Standard error }}{0.0047673}$} & \multirow{3}{*}{$\frac{t \text {-value }}{1.66^{* *}}$} & \multirow{2}{*}{\multicolumn{2}{|c|}{$95 \%$ conf. interval }} & \multicolumn{2}{|c|}{ Collinearity Statistics } \\
\hline & & & & & & Tolerance & VIF \\
\hline & & & & -0.0014934 & 0.0172846 & 0.648 & 1.542 \\
\hline Gender & 0.4254175 & 0.0807006 & 5.27 & 0.2664808 & 0.5843542 & 0.885 & 1.130 \\
\hline Marital status & -0.1039694 & 0.0459260 & $2.26^{* *}$ & -0.1944189 & -0.0135199 & 0.554 & 1.805 \\
\hline Household size & -0.0105441 & 0.0161632 & -0.65 & -0.0423768 & 0.0212886 & 0.825 & 1.212 \\
\hline Income & $-1.12 \mathrm{e}-06$ & $2.95 \mathrm{e}-06$ & $0.38^{* * *}$ & $-6.93 e-06$ & $4.68 \mathrm{e}-06$ & 0.756 & 1.323 \\
\hline Occupation & 0.0366367 & 0.0358896 & 1.02 & -0.0340465 & 0.1073199 & 0.702 & 1.424 \\
\hline Education & -0.0305323 & 0.0497021 & $0.61^{* *}$ & -0.1284187 & 0.0673541 & 0.815 & 1.227 \\
\hline Farm size & 0.1852857 & 0.0670048 & 2.77 & 0.0533223 & 0.3172491 & 0.812 & 1.232 \\
\hline $\begin{array}{l}\text { Per capita } \\
\text { expenditure }\end{array}$ & 0.0001130 & 0.0000458 & $2.46^{* *}$ & 0.0000227 & 0.0002033 & 0.980 & 1.021 \\
\hline Constant & -0.3967158 & 0.2431611 & -1.63 & -0.8756118 & 0.0821803 & & \\
\hline
\end{tabular}

Notes: *** Significant at $1 \%$; ** Significant at $5 \%$; Number of observations $=260$; LR chi-square $(9)=156.55$; Prob $>\chi^{2}=0.0000 ;$ Pseudo $R^{2}=0.8235 ;$ Log likehood $=-228.69065$.

The implication of these is that household heads with an increase in monthly income tend to demand for more kerosene (for cooking and lightening) than household heads with lesser monthly income. Furthermore, changes in the marital status of respondents, from single to married tend to affect the demand for kerosene. Moreover, the positive sign of the level of education shows that educated household heads tend to demand for more kerosene than uneducated ones. It was further revealed that age of the respondents is positively significant. This means that as household heads grow older, their demand for kerosene increases. This could probably be due to fewer rigours and ease of operating kerosene stoves.

Monthly expenditure on kerosene is positively signed and statistically significant. This shows that household heads tend to spend more on kerosene for cooking and lighting. The reason for this is not farfetched from the fact that kerosene constitutes the major source of energy for cooking and lighting in rural communities of Nigeria, except when it is scarce and expensive. Variables such as gender, household size, occupation, and farm size were not statistically significant in determining the demand for kerosene. This implied that gender, household size, occupation, and farm size does not influence the household choice for kerosene.

\subsubsection{Determinants of Electricity}

The result of Tobit regression model as shown in Tab. 7 was used to test the determinants of electricity. The variance inflation factor (VIF) was used to determine the multicollinearity between the explanatory variables. The VIF values were less than 4 . This means that there is no multicollinearity between the variables. The diagnostic statistics of Tobit regression analysis in Tab. 7 reveal that the chi-square value (LRstatistics) for the model is significant at $1 \%$ level which means that the independent variables jointly influence respondents' probability of using Electricity. The Pseudo $R$-squared indicates that $69.9 \%$ of the variance was explained by the explanatory variables. The results in Tab. 7 show that excluding the constant term, out of the eight. The results from the study showed that the coefficients of most of the variables hypothesized to influence household demand for electricity have the expected signs. The results in Tab. 6 show that excluding the constant term, out of the 9 variables that were included in the model, the coefficients of 3 variables were statistically significant at $1 \%$ in influencing household demand for electricity.

The result shows that income $(t=4.54$; $p<0.01)$ and per capita expenditure $(t=0.63$; $p<0.01)$ were negatively significant while occupation $(t=3.36 ; p<0.01)$ was positively significant at $1 \%$ level. The implication of 
Tab. 7: Tobit regression results of factors influencing demand for electricity

\begin{tabular}{|c|c|c|c|c|c|c|c|}
\hline \multirow{3}{*}{$\begin{array}{l}\text { Electricity } \\
\text { Age }\end{array}$} & \multirow{3}{*}{$\begin{array}{l}\text { Coefficient } \\
0.0041009\end{array}$} & \multirow{3}{*}{$\frac{\text { Standard error }}{0.0075802}$} & \multirow{3}{*}{$\frac{t \text {-value }}{0.54}$} & \multirow{2}{*}{\multicolumn{2}{|c|}{$95 \%$ conf. interval }} & \multicolumn{2}{|c|}{ Collinearity Statistics } \\
\hline & & & & & & Tolerance & VIF \\
\hline & & & & -0.0108281 & 0.0190298 & 0.648 & 1.542 \\
\hline Gender & 0.4336050 & 0.1289842 & 0.09 & 0.1795758 & 0.6876343 & 0.885 & 1.130 \\
\hline Marital status & -0.1737767 & 0.0765924 & -2.27 & -0.3246223 & -0.0229310 & 0.554 & 1.805 \\
\hline Household size & -0.0232719 & 0.0268146 & -0.87 & -0.0760822 & 0.0295384 & 0.825 & 1.212 \\
\hline Income & $4.46 \mathrm{e}-06$ & $4.62 \mathrm{e}-06$ & $4.54^{* * *}$ & $-4.63 e-06$ & 0.0000136 & 0.756 & 1.323 \\
\hline Occupation & 0.0052941 & 0.0594233 & $3.36^{* * *}$ & -0.1117378 & 0.1223260 & 0.702 & 1.424 \\
\hline Education & -0.0684586 & 0.0791803 & -0.86 & -0.2244010 & 0.0874837 & 0.815 & 1.227 \\
\hline Farm size & 0.4852631 & 0.1069254 & 0.97 & 0.2746779 & 0.6958484 & 0.812 & 1.232 \\
\hline $\begin{array}{l}\text { Per capita } \\
\text { expenditure }\end{array}$ & 0.0000456 & 0.0000722 & $-0.63^{* * *}$ & -0.0000967 & 0.0001879 & 0.980 & 1.021 \\
\hline Constant & -0.8495936 & 0.4050468 & -2.10 & -1.6473170 & -0.0518701 & & \\
\hline
\end{tabular}

Notes: *** Significant at $1 \%$; ** Significant at 5\%; Number of observations $=260 ;$ LR chi-square $(9)=137.87$; Prob $>\chi^{2}=0.0000 ;$ Pseudo $R^{2}=0.6993 ;$ Log likehood $=-254.4022$.

this is that increase in the monthly income of the respondents will increase the demand for electricity for cooking and lighting while lower-income reduce the electricity demand. Also, an increase in actual expenditure on electricity may not really reflect demand due to the erratic nature of power supply in rural communities of Nigeria. However, it is expected that usage of electricity either for cooking or lighting will increase monthly electricity bills. Furthermore, household heads with better jobs could afford electricity as their major source of energy for cooking and lighting compared with those with lesser pay that could not afford it. Variables such as age, marital status, gender, household size, education, and farm size were not statistically significant in determining the demand for electricity. This implied that age, marital status, gender, household size, education, and farm size does not influence the household choice for electricity.

\subsection{Relationship between Fuel Price and Consumption Rate}

From the summary of $F$-statistics ANOVA (Analysis of Variance) presented in Tab. 8, results revealed that fuel price of fuelwood $(F=6.159 ; p<0.05)$ and charcoal $(F=$ 8.827; $p<0.05)$ is significantly related with consumption. This finding is similar to the results of Bisu et al. (2016), Lee (2013) and Oyedepo (2012) that lower prices of fuelwood and charcoal tend to increase consumption rate in developing countries especially among poorer households. On the other hand, increase in the rate of consumption is not significantly related to the price of kerosene $(F=2.427 ; p>0.05)$ and electricity $(F=1.759 ; p>0.05)$. This means that the consumption of kerosene and electricity is not a function of their prices. This is probably due to the recent increase in the price of kerosene and electricity charges which has reduced the consumption rate of kerosene and electricity among households in the study area. As a result of this, most of the residents in the study area switched to alternative means of domestic energy sources. This finding does not agree with the submission of Bisu et al. (2016) concerning the significant relationship between fuel price and the consumption rate of kerosene. The reason is probably due to an increase in the unit price of kerosene in the country. Nevertheless, this study agrees with Bisu et al. (2016) who observed no significant relationship between fuel price and consumption rate of electricity. It could be inferred that the consumption of kerosene and electricity is independent on price while the consumption of fuelwood and charcoal is dependent on price. 
Tab. 8: Relationship between consumption rate and fuel price

\begin{tabular}{|c|c|c|c|c|c|c|}
\hline & & Sum of squares & df & Mean square & $\mathbf{F}$ & Sig. \\
\hline \multirow[t]{3}{*}{ Fuelwood } & Between Groups & 76849.794 & 3 & 25616.598 & 6.159 & $p<0.05$ \\
\hline & Within Groups & 1064768.668 & 256 & 4159.253 & & \\
\hline & Total & 1141618.462 & 259 & & & \\
\hline \multirow[t]{3}{*}{ Charcoal } & Between Groups & 84823.250 & 3 & 28274.417 & 8.827 & $p<0.05$ \\
\hline & Within Groups & 820004.054 & 256 & 3203.141 & & \\
\hline & Total & 904827.304 & 259 & & & \\
\hline \multirow[t]{3}{*}{ Kerosene } & Between Groups & 559959.690 & 3 & 186653.230 & 2.427 & $p>0.05$ \\
\hline & Within Groups & 19685185.276 & 256 & 76895.255 & & \\
\hline & Total & 20245144.965 & 259 & & & \\
\hline \multirow[t]{3}{*}{ Electricity } & Between Groups & 805318.060 & 3 & 268439.353 & 1.759 & $p>0.05$ \\
\hline & Within Groups & 39064860.402 & 256 & 152597.111 & & \\
\hline & Total & 39870178.462 & 259 & & & \\
\hline
\end{tabular}

\subsection{Discussion}

The above results reflected the existing situation among rural households in the study area. It could be observed that fuelwood, charcoal, and kerosene were dominantly used for cooking and heating while electricity was majorly used for lighting. Compared to the result of other studies (Bisu et al., 2016; Ogwumike et al., 2014), there is little improvement in the use of kerosene for cooking in the study area. Lack of access to electricity has caused no improvement in the use of electricity for cooking. Increase in the use of fuelwood and charcoal has resulted in deforestation in most parts of the study area. It has also contributed to indoor pollution. Overdependent on fuelwood and charcoal as noted by Adepoju et al. (2012), Nnaji et al. (2012), and Onyekuru et al. (2020) is not environmentally friendly and has a major effect on human health. The heavy use of wood and charcoal may be a result of low monthly income (see Tab. 3) as most of the rural households were left with no alternative than to source for cheap energy locally. It may also be a result of inconsistency in the supply of electricity. Little improvement in the use of kerosene for cooking and heating was as a result of its availability through investment in infrastructure such as filling station. However, the hike in price of kerosene has caused the majority not to rely heavily on the usage of kerosene for cooking and heating as well as lighting.
The results of the model further show that income is not the major factor influencing the use of kerosene, fuelwood, charcoal, and electricity, other factors were also affecting the choice of energy. It could be inferred that different domestic energy sources have their peculiarity with regard to the associated determinants. For example, factors such as gender, household size, income, occupation, farm size, and per capita expenditure were significant in influencing the use of fuelwood; age, gender, household size, occupation, education, and per capita expenditure for charcoal, while age, marital status, income, education and per capita expenditure were significant determinants in the use of kerosene. Also, income, occupation, and per capita expenditure were the factors influencing the use of electricity among rural households in the study area. The result of this model, therefore, negates the assumption of the energy ladder model which states that households tend to improve in the use of energy for cooking, heating \& lighting as income increases. This study agrees with the assumption of fuel stacking model on the use of energy.

The results of this study corroborated the finding of Jan et al. (2012) who, in a study to investigate determinants of rural household energy choices, found out that income is not the only determinant of transition from traditional to more convenient form of energy, other factors also account for household energy choice. The 
result is in agreement with the findings of Adamu et al. (2020) who examined household energy consumption and discovered that energy ladder theory only provides a limited view of reality in households. Beyond income, there are other closely interrelated socio-economic factors that drive household energy transition. This study, therefore, presents the need for further investigation into other factors which influence the choice of energy consumption in urban and rural area in one study. This could also be replicated in peri-urban of major cities of Nigeria.

\section{CONCLUSION}

This study has assessed factors influencing household energy demand in Ese-Odo Local government area of Ondo State, Nigeria. The study specifically investigates household energy use and the determinants of energy usage among rural households. The study employed descriptive statistics, ANOVA, and Tobit regression model to analyze data collected from 260 randomly sampled household heads in the study area. The results revealed that $66.5 \%$ of the household heads were males while $33.3 \%$ were female. Also, a larger proportion of the household heads $(97.0 \%)$ earned earn below $\$ 55,000$ (143.9\$) while only $3.0 \%$ earned above $\$ 55,001$ (143.9\$) per month with an average income of $\$ 26,896.15$ (70.4\$). The study established that the majority of the respondents $(71.5 \%)$ were between 31 - 60 years of age. The common usage of fuelwood was for cooking (38.5\%), heating (33.3\%), and lighting $(5.7 \%)$ while charcoal was used for cooking $(8.9 \%)$, heating $(13.9 \%)$, and lighting $(1.9 \%)$. Kerosene was widely used for cooking $(48.1 \%)$, lighting (37.7\%), and heating (40.3\%). With reference to the determinants of household energy for lighting, heating, and cooking, the results of Tobit regression revealed that gender, household size, income, occupation, farm size, and per capita expenditure were significant in influencing the use of fuelwood; age, gender, household size, occupation, education and per capita expenditure for charcoal, while age, marital status, income, education and per capita expenditure were significant determinants in the use of kerosene. Also, income, occupation, and per capita expenditure were the factors influencing the use of electricity among rural households in the study area. It could be inferred that household income is not the only factor affecting household energy choices, other factors also contribute to it. This however negates the assumption of the energy ladder model on the income, being the central driver of energy choice. This study, therefore, agrees with Jan et al. (2012) and Adamu et al. (2020) that income is not the most important variable affecting the energy choice of households.

The study revealed that per capita expenditure on kerosene and electricity is high when compared with fuelwood and charcoal. The study also revealed that there is a relationship between the rate of consumption and fuel price of firewood and charcoal while there is no significant relationship between the rate of consumption and fuel price of kerosene and electricity. The study discovered that lesser fuel prices and per capita expenditure on firewood and charcoal were the major reasons that make households to prefer firewood and charcoal over other energy types in the study area. However, the observation of Adepoju et al. (2012) is that over-dependence on the usage of biofuel (such as fuelwood and charcoal) has contributed to the deforestation of rural communities and has the tendency to increase indoor environmental pollution. In order for rural communities of Nigeria to access 2030 SDGs more easily, there is need for the government or stakeholders to formulate and implement policies that will ensure easy access to safe, reliable, and clean modern energy services

The study, therefore, encourages the government to put in place sustainable modern energy that is reliable, affordable, and convenient for everyone with fewer implications to the health of the individual and the environment. The study concluded that apart from income, other household variables were significant in 
determining energy usage. The study, therefore, recommended that government and stakeholders should develop policies that will promote the use of modern energy sources that is safe, reliable, and clean in order to reduce the negative environmental consequences while also enhancing human life quality. Efforts should also be made by the government or stakeholders in providing incentives for households that will encourage the consumption of sustainable energy sources. This will not only improve energy consumption in rural areas but will also make rural communities to access 2030 SDGs more easily.

\section{REFERENCES}

Adamu, M. B., Adamu, H., Ade, S. M. and Akeh, G. I. 2020. Household Energy Consumption in Nigeria: A Review on the Applicability of the Energy Ladder Model. Journal of Applied Science, Environment and Management, 24 (2), 237-244. DOI: $10.4314 /$ jasem.v24i2.7.

Adepoju, A. O., Oyekale, A. S. and Aromolaran, O. 2012. Rural Households' Demand for Domestic Energy in Odeda Local Government Area (LGA) of Ogun State, Nigeria. Journal of Human Ecology, 40 (2), 115-123. DOI: $10.1080 / 09709274.2012 .11906529$.

Adetayo, O. D., Adeyinka, S. A. and Agbabiaka, H. I. 2020. Domestic Energy Usage and Its' Health Implication on Residents of the Ese-Odo and Okitipupa Local Government Areas of Ondo state, Nigeria. Environmental Quality Management, 29 (3), 51-61. DOI: 10.1002/tqem.21681.

Adetunji, M. O., Adesiyan, I. O. and Sanusi, W. A. 2007. Household Energy Consumption Pattern in Osogbo Local Government Area of Osun State. Pakistan Journal of Social Sciences, 4 (1), 9-13.

Amore, M. D. and Murtinu, S. 2019. Tobit Models in Strategy Research: Critical Issues and Applications. Global Strategy Journal, 1-25. DOI: $10.1002 /$ gsj.1363.

Babanyara, Y. Y. and SAleh, U. F. 2010. Urbanization and the Choice of Fuelwood as a Source of Energy in Nigeria. Journal of Humanities Ecology, 31 (1), 19-26. DOI: 10.1080/09709274.2010.11906293.

Barnes, D. F. and Floor, W. M. 1996. Rural Energy in Developing Countries: A Challenge for Economic Development. Annual Review of Energy and the Environment, 21, 497-530. DOI: 10.1146/annurev.energy.21.1.497.

Bhattacharyya, S. C. 2011. Energy Economics: Concepts, Issues, Markets and Governance. London: Springer Verlag.

Bisu, D. Y., Kuhe, A. and Iortyer, H. A. 2016. Urban Household Cooking Energy Choice: An Example of Bauchi Metropolis, Nigeria. Energy, Sustainability and Society, 6 (1), 15. DOI: $10.1186 /$ s13705-016-0080-1.
Bonjour, S., Adair-Rohani, H., Wolf, J., Bruce, N. G., Mehta, S., Prüss-Ustün, A., Lahiff, M., Rehfuess, E. A., Mishra, V. and Smith, K. R. 2013. Solid Fuel Use for Household Cooking: Country and Regional Estimates for 1980-2010. Environmental Health Perspectives, 121 (7), 784-790. DOI: 10.1289/ehp.1205987.

Buba, A., Abdu, M., Adamu, I., Jibir, A. and Usman, Y. I. 2017. Socio-Economic Determinants of Households Fuel Consumption in Nigeria. International Journal of Research - Granthaalayah, 5 (10), 348-360. DOI: 10.5281/zenodo.1046324.

Chukwu, P. U., Ibrahim, I. U., Ojosu, J. O. and IorTyer, H. A. 2014. Sustainable Energy Future for Nigeria: The Role of Engineers. Journal of Sustainable Development Studies, 6 (2), 242-259.

de Abreu, M. W., Ferreira, D. V., Pereira, A. O., Cabral, J. and Cohen, C. 2021. Household Energy Consumption Behaviors in Developing Countries: A Structural Decomposition Analysis for Brazil. Energy for Sustainable Development, 62, 1-15. DOI: 10.1016/j.esd.2021.03.001.

Démurger, S. and Fournier, M. 2011. Poverty and Firewood Consumption: A Case Study of Rural Households in Northern China. China Economic Review, 22 (4), 512-523. DOI: $10.1016 /$ j.chieco.2010.09.009.

EAKINS, J. 2013. An Analysis of the Determinants of Household Energy Expenditures: Empirical Evidence from the Irish Household Budget Survey. $\mathrm{PhD}$ thesis, University of Surrey, UK.

Edwards, J. H. and LAngPap, C. 2008. Fuel Choice, Indoor Air Pollution, and Children's Health. Working Paper No. 0803. Tulane University.

Egaña Del Sol, P. A. and Flanders, S. 2020. Platform Economy and Sustainable Energy. In Leal Filho, W., Azul, A., Brandli, L., ÖZUYAR, P. and WAll, T. (eds.). Affordable and Clean Energy. Encyclopedia of the UN Sustainable Development Goals. Springer, Cham. DOI: 10.1007/978-3-319-71057-0_36-1. 
Elias, R. J. and Victor, D. G. 2005. Energy Transitions in Developing Countries: A Review of Concepts and Literature. Working Paper No. 40. Stanford University.

Emagbetere, E., Odia, J. and Oreko, B. U. 2016. Assessment of Household Energy Utilized for Cooking in Ikeja, Lagos State, Nigeria. Nigerian Journal of Technology, 35 (4), 796-804. DOI: $10.4314 /$ njt.v35i4.14.

Energy Sector Management Assistance Programme (ESMAP). 2000. Energy and Development Report 2000: Energy Services for the World's Poor. Washington, DC.

Energy Sector Management Assistance Programme (ESMAP). 2003. Household Fuel Use and Fuel Switching in Guatemala. Joint UNDP/World Bank Energy Sector Management Assistance Project.

Farsi, M., Filippini, M. and Pachauri, S. 2007. Fuel Choices in Urban Indian Households. Environment and Development Economics, 12 (6), 757-774. DOI: $10.1017 /$ S1355770X07003932.

Green, S. B. and SAlkind, N. J. 2010. Using SPSS for Windows and Macintosh: Analyzing and Understanding the Data. 5th ed. Upper Saddle River, NJ: Pearson Education.

Güney, T. and Kantar, K. 2020. Biomass Energy Consumption and Sustainable Development. International Journal of Sustainable Development \& World Ecology, 27 (8), 762-767. DOI: $10.1080 / 13504509.2020 .1753124$.

Gwatkin, D. R., Rutstein, S., Johnson, K., Pande, R. P. and WagstafF, A. 2000. Socio-Economic Differences in Health, Nutrition, and Population in Nigeria. HNP/Poverty Thematic Group of the World Bank.

Hair, J. F., Black, W., Babin, B., Anderson, R. and Tatham, R. 2006. Multivariate Data Analysis. 6th ed. Upper Saddle River, NJ: Pearson Prentice Hall.

Heltberg, R. 2004. Fuel Switching: Evidence from Eight Developing Countries. Energy Economics, 26 (5), 869-887. DOI: 10.1016/j.eneco.2004.04.018.

Heltberg, R. 2005. Factors Determining Household Fuel Choice in Guatemala. Environment and Development Economics, 10 (3), 337-361. DOI: $10.1017 / \mathrm{S} 1355770 \mathrm{X} 04001858$.

Herington, M. J. and Malakar, Y. 2016. Who is Energy Poor? Revisiting Energy (In)security in the Case of Nepal. Energy Research \& Social Science, 21, 49-53. DOI: 10.1016/j.erss.2016.06.025.

Hussainey, K. and Al-NajJar, B. 2011. FutureOriented Narrative Reporting: Determinants and Use. Journal of Applied Accounting Research, 12 (2), 123-138. DOI: 10.1108/09675421111160691.

International Energy Agency (IEA). 2013. World Energy Outlook 2013.
International Energy Agency (IEA). 2014. Developing Energy Efficiency Indicators to Track Efficiency Progress: Why? IEA Energy Efficiency Market Report.

Jan, I., Khan, H. and Hayat, S. 2012. Determinants of Rural Household Energy Choices: An Example from Pakistan. Polish Journal of Environmental Studies, 21 (3), 635-641.

Kichonge, B., John, G. R., Mkilaha, I. S. N. and Hameer, S. 2014. Modelling of Future Energy Demand for Tanzania. Journal of Energy Technology and Policy, 4 (7), 16-31

Kowsari, R. and Zerriffi, H. 2011. Three Dimensional Energy Profiles: A Conceptual Framework for Assessing Household Energy Use. Energy Policy, 39 (12), 7505-7517. DOI: 10.1016/j.enpol.2011.06.030.

Kune, A. and Bisu, D. Y. 2019. Influence of Situational Factors on Households' Energy Consumption Behaviour: Towards an Effective Energy Policy. International Journal of Energy Sector Management, 14 (2), 389-407. DOI: 10.1108/IJESM-03-2019-0017.

LeE, L. Y.-T. 2013. Household Energy Mix in Uganda. Energy Economics, 39, 252-261. DOI: 10.1016/j.eneco.2013.05.010.

Leiwen, J. and O'Neill, B. C. 2003. The Energy Transition in Rural China [online]. International Institute for Applied Systems Analysis (IIASA), IR-03-070. Available at: http://pure.iiasa.ac.at/7015.

[Accessed 2021, January 28].

Leth-Petersen, S. 2002. Micro Econometric Modelling of Household Energy Use: Testing for Dependence between Demand for Electricity and Natural Gas. The Energy Journal, 23 (4), 57-84. DOI: $10.2307 / 41323461$.

Malla, S., Timilsina, G. R. 2014. Household Cooking Fuel Choice and Adoption of Improved Cookstoves in Developing Countries: A Review. Policy Research Working Paper No. 6903. The World Bank Development Research Group.

Masera, O. R., SaAtkamp, B. D. and Kammen, D. M. 2000. From Linear Fuel Switching to Multiple Cooking Strategies: A Critique and Alternative to the Energy Ladder Model. World Development, 28 (12). 2083-2103. DOI: $10.1016 / \mathrm{S} 0305-750 \mathrm{X}(00) 00076-0$.

Mazibuko, N. V. E. and Antwi, M. A. 2019. Socio-Economic Factors Influencing Smallholder Farmers Agricultural Infrastructure Availability, Accessilibility and Satisfaction: A Case on North West Province in South Africa. OIDA International Journal of Sustainable Development, 12 (5), 11-26. 
Mekonnen, A. and Köhlin, G. 2008. Determinants of Household Fuel Choice in Major Cities in Ethiopia. Working paper in Economics No. 399. University of Gothenburg.

Mensah, J. T. and Adu, G. 2013. An Empirical Analysis of Household Energy Choice in Ghana. Working paper No. 6. Swedish University of Agricultural Sciences.

Modi, V., McDade, S., Lallement, D. and SAGHiR, J. 2005. Energy Services for the Millennium Development Goals. New York: Energy Sector Management Assistance Programme, United Nations Development Programme, UN Millennium Project, and World Bank.

NaibBi, A. I. and Healey, R. G. 2013. Northern Nigeria's Dependence on Fuel Wood: Insights from Nationwide Cooking Fuel Distribution Data. International Journal of Humanities and Social Science, 3 (17), 160-173.

Nlom, J. H. and Karimov, A. A. 2015. Modeling Fuel Choice among Households in Northern Cameroon. Sustainability, 7 (8), 9989-9999. DOI: $10.3390 /$ su7089989.

Nnaji, C. E., Ukwueze, E. R. and Chukwu, J. O. 2012. Determinants of Household Energy Choices for Cooking in Rural Areas: Evidence from Enugu State, Nigeria. Continental Journal of Social Sciences, 5 (2), 1-11.

Odah, M. H., Bager, A. S. M. and Mohammed, B. K. 2017. Tobit Regression Analysis Applied on Iraqi Bank Loans. American Journal of Mathematics and Statistics, 7 (4), 179-182. DOI: $10.5923 /$ j.ajms.20170704.06.

Ogwumike, F. O., Ozughalu, U. M. and Abiona, G. A. 2014. Household Energy Use and Determinants: Evidence from Nigeria. International Journal of Energy Economics and Policy, 4 (2), 248-262.

Oke, J. A., Akinkunmi, W. B. and Etebefia, S. O. 2019. Use of Correlation, Tolerance and Variance Inflation Factor for Multicollinearity Test. Global Scientific Journals, 7 (5), 652-659.

Olagunju, F. I. and Ajiboye, A. 2010. Agricultural Lending Decision: A Tobit Regression Analysis. African Journal of Food Agriculture Nutrition and Development. 10 (5), 2515-2541. DOI: 10.4314/AJFAND.V10I5.57897.

OnojA, A. O. and Idoko, O. 2012. Econometric Analysis of Factors Influencing Fuel Wood Demand in Rural and Peri-Urban Farm Households of Kogi State. Consilience: The Journal of Sustainable Development, 8 (1), 115-127.
Onyekuru, N. A., Ifejirika, C. A., Onuigbo, D. M. Mebo, R. A. and Евон, E. C. 2020. Factors Affecting Households' Choice of Cooking Energy in Enugu State, Nigeria. Agro-Science, 19 (4), 6-13. DOI: 10.4314 /as.v19i4.2.

Onyekuru, N. A. and Евон, E. C. 2011. Determinants of Cooking Energy Demand in the Rural Households of Enugu State, Nigeria: An Application of the Bivariate Probit Model. Asian Journal of Experimental Biology Science, 2 (2), 332-335.

Osiolo, H. 2009. Enhancing Household Fuel Choice and Substitution in Kenya. KIPPRA Discussion Paper No. 102.

Oyedepo, S. O. 2012. Energy and Sustainable Development in Nigeria: The Way Forward. Energy, Sustainability and Society, 2 (1), 15.

Pachauri, S. 2004. An Analysis of Cross-Sectional Variations in Total Household Energy Requirements in India Using Micro Survey Data. Energy Policy, 32 (15), 1723-1735.

DOI: $10.1016 / \mathrm{S} 0301-4215(03) 00162-9$.

Pachauri, S. and Spreng, D. 2004. Energy Use and Energy Access in Relation to Poverty. Economic \& Political Weekly. 39 (3). 272-278.

Rahmani, O., Rezania, S., Beiranvand Pour, A., Aminpour, S. M., Soltani, M., Ghaderpour, Y. and Oryani, B. 2020. An Overview of Household Energy Consumption and Carbon Dioxide Emissions in Iran. Processes, 8 (8), 994. DOI: $10.3390 /$ pr8080994.

SaAtkamp, B. D., Masera, O. R. and Kammen, D. M. 2000. Energy and Health Transitions in Development: Fuel Use, Stove Technology and Morbidity in Jarácuaro, México. Energy for Sustainable Development, 4 (2), 7-16.

Schlag, N. and Zuzarte, F. 2008. Market Barriers to Clean Cooking Fuels in Sub-Saharan Africa: A Review of Literature. Working paper. Stockholm Environment Institute.

Song, N., Aguilar, F. X., Shifley, S. R. and Goerndt, M. E. 2012. Factors Affecting Wood Energy Consumption by U.S. Households. Energy Economics, 34 (2), 389-397. DOI: $10.1016 /$ j.eneco.2011.12.009.

Svoboda, P. and BrČÁk, J. 2013. Electricity Consumption Demand Model in Czech Households. International Advances in Economic Research, 19 (1), 63-64. DOI: 10.1007/s11294-012-9384-x.

UN (United Nations). 2013. A New Global Partnership: Eradicate Poverty and Transform Economies through Sustainable Development. The Report of the High-Level Panel of Eminent Persons on the Post-2015 Development Agenda. 
VAN DER Kroon, B., Brouwer, R. and VAN Beukering, P. J. H. 2013. The Energy Ladder: Theoretical Myth or Empirical Truth? Results from a Meta-Analysis. Renewable and Sustainable Energy Reviews, 20, 504-513. DOI: $10.1016 /$ j.rser.2012.11.045.

Verbeek, M. 2004. A Guide to Modern Econometrics. 2nd ed. John Wiley \& Sons.

WARsco, K. 1994. Conventional Fuel Displacement by Residential Wood Use. Forest Products Journal, 44 (1), 68-74.

WHO. 2006. Fuel for Life: Household Energy and Health [online]. Available at: https://www . who.int/publications/i/item/9789241563161. [Accessed 2020, December 20].

WHO. 2010. Household Air Pollution and Health [online]. Available at: http://www.who.int/ mediacentre/factsheets/fs292/en/. [Accessed 2020, December 20].

Wilson, E. 2012. Energy Equity: Can the UN Sustainable Energy for All Initiative Make a Difference? [online]. International Institute for Environment and Development. Available at: https://www.iied.org/ energy-equity-can-un-sustainable-energy -for-all-initiative-make-difference. [Accessed 2020, June 15].
World Bank. 2003. Household Energy Use in Developing Countries, a Multicountry Study. UNDP/World Bank Energy Sector Management Assistance Programme (ESMAP).

World Energy Council. 2016. World Energy Resources [online]. Available at: https://www . worldenergy . org/assets/images/imported/2016/ 10/World-Energy-Resources-Full-report-2016. 10.03.pdf. [Accessed 2020, December 25].

Wuyuan, P., Zerriffi, H. and Jihua, P. 2008. Household Level Fuel Switching in Rural Hubei. PESD Working Paper No. 79.

Yamamoto, S., Sié, A. and Sauerborn, R. 2009. Cooking Fuels and the Push for Cleaner Alternatives: A Case Study from Burkina Faso. Global Health Action, 2 (1), 2088. DOI: $10.3402 /$ gha.v2i0.2088.

Yonemitsu, A., Nuenga, M., Iiyama, M. and Matsushita, S. 2015. A Choice Experiment Study on Fuel Preference of Kibera Slum Households in Kenya. International Journal of Environment Science Development, 6 (3), 196-200. DOI: $10.7763 /$ IJESD.2015.V6.589.

Yu, B., Zhang, J. and Fujiwara, A. 2012. Analysis of the Residential Location Choice and Household Energy Consumption Behaviour by Incorporating Multiple Self-Selection Effects. Energy Policy, 46, 319-334. DOI: 10.1016/j.enpol.2012.03.067.

\section{AUTHOR'S ADDRESS}

Olorunjuwon David Adetayo, Department of Urban and Regional Planning, Obafemi Awolowo University, e-mail: kidex4real@yahoo.com

Gbenga John Oladehinde, Department of Urban and Regional Planning, Obafemi Awolowo University, e-mail: gbengom@gmail.com

Samson A. Adeyinka, Department of Urban and Regional Planning, Obafemi Awolowo University, e-mail: adeyinkasa@yahoo.co.uk

Adejompo Fagbohunka, Department of Geography and Planning Sciences, Adekunle Ajasin University, Akungba-Akoko, Nigeria, e-mail: adejompofagbohunka@gmail.com 